\title{
TEMASIK: BETWEEN CONVENTION AND INVENTION
}

\author{
Siti Hajar Che Man \\ shajar@usm.my
}

School of Humanities, Universiti Sains Malaysia, 11800 USM, Pulau Pinang, Malaysia. Tel.:+604-6532865

\begin{abstract}
This article focusses on the issue of style of presentation by some Singapore short story writers on the livelihood among the Singapore society in the era of ' 65 leading to the early 90's. Temasik (short story anthology by Singapore writers) published by the Dewan Bahasa dan Pustaka in 1987 and edited by Suratman Markasan is chosen for the purpose. Each and every short story in this anthology portrayed the what, where, who, how and when of the Singapore society after 1965 which later became the rigours of livelihood till today. The issues touched upon by the writers are analysed based on the existence of the inter-relation of two dimensions-namely the concept of the creation of creative works and the observation of its continuity and layering between invention and convention. The first concept deals with the bond between reality, imagination, illusion and fantasy whereas the second concept deals with the combination between the pattern of story telling which also mirrors the maturity and experience of the short story writers of the 80 's. The Temasik anthology is not only seen as a catalyst, but also as an impetus toward the production of creative works of quality, apart from ushering the emergence of Singapore writers and works in the era of e-literature.
\end{abstract}

Keywords : Temasik, creative works, convention, invention, e-literature 


\section{INTRODUCTION}

How truthful can 1965 be seen ' 65 as a tragic moment for Malaysia and Singapore which to the naked eye seemed as being separated only by the Johore causeway? Several questions arise as to whether they were prejudicial, sympathatic, curious, as to the why and wherefore? What had happened? Why the need for separation? And the most sensational and sensitive question was how and what would be the destiny of the Malays? In actual fact ' 65 was a sacred year that brought a host of interpretations, signs and meanings toward the relationship between Malaysia and Singapore. The connection between both these countries was more meaningful with the acceptance of the literary discpline as a platform to strengthen the camaraderie between both countries which are intimate in the geo-political, geography and sociocultural aspects. Such closeness was further cemented with the signing of the inaugural Regional Conference on Malaysia-Singapore Malay Literature post 1965 dimension, hosted by the Department of Literature and Malay Language Council of Singapore with the cooperation of the Dewan Bahasa dan Pustaka, Kuala Lumpur. The theme of the conference was change and continuity, focusing on Malay literature and the development of identity. How effective was the role of literature as a substantial platform in realizing that Malaysia and Singapore were separated only in geo-political term, whereas from the standpoint of soul, inner self, psyche and emotion it was still "prick the left thigh and the right thigh would feel it too", or this intimacy is very much "tear out the chicken feather and it would get back together again", or "to cut the flow of water would never sever it", and indeed this relationship would also be translated as a parable to the English proverb, blood is thicker than water.

The development of literature in Singapore is an extension of the post ' 65 era. During this time reknowned writers emerged and became famous after writing seriously as members of Angkatan Sasterawan 50 (Asas 50), among them for example, Mohamed Latiff Mohammed, Djamal Tukimin, Mohammad Taha Jamil and Yatiman Yusof. This group of writers are the successors who fought for the Malay literature that was initiated by Masuri SN and Suratman Markasan. Further development in the " 65 era was a catalytic to its continuity in the 70's which enlivened the Malay literature. A group of spirited Singapore writers emerged in the 70's that painted the literary world, apart from being proactive as literary activists. As a result the effort by this pioneering group produced 398 short stories at the end of 
the 70's era (Mohamed Pitchay Gani, 2005:10). The 80's was the literary apex in Singapore, marked by the S.E.A. write awards given to Masuri SN and Suratman Markasan.

In congruence with the theme of Change and Continuity: Malay Literature and the Creation of Identity, and on the basis of fulfulling the assertion of fraternity and the spirit of friendship between Malaysia and Singapore, the working paper chose Temasik, an anthology of short stories published in the 80 's. It is a compilation of works written by fifteen Singapore writers who had penned about the diversity of life of the locals via themes and issues that depicted the relationship between literature and culture, and the interpolation between reality, illusion, imagination and fantasy. Edited by the reknown Suratman Markasan, the anthology was published in 1987 by Dewan Bahasa dan Pustaka (the Language and Literary Institute), Kuala Lumpur. The anthology presented to the audience the writing styles, attitudes and the thoughts of Singapore short story writers, namely Ahmad Affandi, Ahmad Awang, Abd. Wahab Hj. Hamzah, Iswardy, Ismail Sarkawi, Jamal Ismail, Muhammad Ariff Ahmad, Masuri SN, Mohamed Fuad Salim, Mohamed Latiff Mohamed, Noor Hidayat, Noor S.I, Peter Augustine Goh and Suratman Markasan. Most of the short stories chosen in the anthology are those which were published singly in Berita Minggu (Singapore) and Dewan Sastera. Although it is said that the era of the 80's was the height of the development of literature due to the impetus created by the Literary Prize which began in 1975, but there existed a feeling of frustration among the Singapore literary thinkers. As an example, Suratman Markasan and the committee that selected the short stories for this anthology felt (1987: x),

From the list of names mentioned and a few others, the number of writers that could produce good and proven short story was still small. We could see this fact, as incidentally we sat as members of the Singapore Literary Prize in the short story and novel section. Therefore, while compiling the 20 short stories, we faced the difficulty of finding 20 short story writers...

Based on this opinion, it could be deduced that the choice of the short stories in the anthology Temasik went through a stringent selection among the best writers. The choice was a mixture of proactive and prolific writers in the development of Singapore short story. Their names continued to shine in the 90's until the emergence of e-literature. 


\section{TEMASIK: A CONCEPT OF THE CREATION OF WORKS}

A unique fact about Temasik is there was no short story bearing the name of Temasik in this anthology and made me curious about its title. Usually, in an anthology of short story, a particular short story would be chosen as its title. This fact made the choice of this anthology an interesting research material for the conference. The term "Temasik" surely had an implisit meaning. Studying each and every one of the twenty short stories, I decided to name this working paper "A Collection of Singapore Malay Life Styles". It simultaneously described as to how each writer tries to portray the life style, attitude, thoughts, practices and the problems they faced in the era. Could it be that the life style depicted by these 80 's short story writers was reciprocal of the life style before ' 65 , or probably what was displayed via the twenty short stories was indeed the impetus to the individual and societal change, or perhaps a catalyst toward the creation of identity? Therefore, the short story writers in this era and the anthology Temasik could provide the answer to the issue.

Generally, short story as a genre is tied to the convention that requires the creation of the work to subscribe to the structural elements that function in the development of an idea that the writer tries to depict. But, during the establishment of the short story genre, the convention was challenged by the emergence of structurally deviant short stories that came up with a story telling and content that was difficult to comprehend, planned or guess its ending. This was the result each idea was intertwined with fictional elements that produced a story teling known as "unusual" or "non-conventional". The story telling could be classified as mimetic fiction, dream fiction or even premise fiction and cult fiction. Each classification is tied to the combination between reality, imagination, illusion and fantasy. This combination highlighted the strength and ability of the writer in mixing experience, observation and research during the process of writing. Can this be traced in Temasik?

\section{THE DEFINITION OF CONCEPTS:}

\section{Convention}

Normally, the term convention meant the ways and methodology readily acceptable by most members of society (Ali Ahmad, 1998:5). Therefore, this definition provided room for story telling which is used repetitively in literary works, including the short story genre. In other words convention can be 
defined as available characteristics which should be followed in describing a particular idea. In the traditional Malay literature, the conventional law in describing diverse ideas was faithfully subscribed. This is evident from the way the story is told in a repititive manner, for example the description about nature, princes, step mothers, heroes and heroines which had little difference from one story to another. According to Hashim Awang (1987: 52), convention or conventional may also be ascribed to as a guideline, theme, style or literary form which had been generally accepted as in the construction of a pantun.

\section{Invention}

The opposite of convention is invention or innovation. Generally, the term invention refers to a creation, whereby the author of fiction (a story and fiction) could escape from conventional demands by taking into consideration that an author uses his or her talent in inventing something new. Seemingly, this situation does not warrant a robber to be handed a punitive ending. This also does not mean a hero must eventually marry the heroine and live happily ever after. A hero need not be muscular, handsome and in the context of invention the hero could emerge as a timid youth, even shabbily dressed. The meaning of invention also influences the structure of story telling. This change involves maturity and experience of the author who cleverly deploys a story telling style with the flow that eventually stamps issues for the audience to ponder. Likewise, invention may also be termed as in-conventional,non-conventional, irrational, style@new style, unusual short story, abnormal, different and deviant, new idea, new interest and so forth.

But not all authors are successful in eluding the conventional laws and not all authors are skillful in exploiting all the literary elements to its maximum and thereby challenge convention. Non-conventional meant there existed a different and a new inclination as to how a story or an issue could be depicted in a fiction. The development of characterization, plot combination, style, point of view and the characters could be viewed more explicitly. This sort of creation displayed that the authors intertwine the sensitive elements together with creavity and imagination. It could be said the authors from this group try to erode the conventional creative pattern which is deemed unable to engage in a dialogue and having a monologue on complex and sophisticated issues of humanity. Therefore, the status of realism which stood strong for decades eventually faced a powerful challenge. Various terms were given to 
this new stream of writing, such as introverted novel, anti-novel, irrealism, surfiction, new fiction, fabulation, magical realism and metafiction. This approach announces this sort of style as being anti-character, anti-plot, antimessage and anti-reality. Creative invention is no more tied to the causal effect as found in conventional features.

\section{TEMASIK: CONVENTION AND INVENTION}

How did the weaving and streaming of the concept of convention and invention flowed via the short story writers in the anthology Temasik? To answer the question let us take a closer look on the opinion of Suratman Markasan as the editor of Temasik, and he was with the view, "moving on from the short stories in Berita Minggu, 1997-1979, we found that the writers did not venture into new grounds. In other words, they were still writing almost the same way as their predecessors, whether it was in terms of theme, plot, presentation etc (1987:x). Based on such opinion, I quote the dictions "new grounds". Such terms clarified the meaning of invention. However, from the works of several prolific writers, for example Md. Fuad Salim, Mohammed Latif Mohammed, Jamal Ismail and Ismail Sarkawi came short stories which did not only pursue new and fresh themes, but with new plots and good language, that stimulated the desire to read their short stories repeatedly. Apart from that the short stories invited the audience to think, as their contents were filled with insinuations that needed to be understood and explained.

The flow of the short story, "Ke mana Hati Hendak Kubawa" (Where Would I Bring My Heart), by M. Fuad Salim, "Mondok" by Mohammed Latif Mohammed and "Lembu" (Cow) and "Menanti Hari Pembalasan" (Waiting for the Judgement Day) by Ismail Sarkawi, uses the element of fauna and an animal as the main character. The writer creatively attempted to understand the emotion and situation, as well as the desire of the animals. What was interesting, the animals did not only narrate perfectly, but they require the readers to ponder about the issues put forward. With a good beginning, this short story succeeded in drawing the interest of the reader until the ending part, but the denouement seemed incomplete. Fuad brought up a question whether it was the real kind of freedom that man yearned for? Whereas Mohammed Latif Mohammed and Ismail Sarkawi tried to present a kind of pressure imposed by powerful men on to the weak. And the short story "Di Tengah Pemimpin" (Amidst the Leader) by Suratman Markasan 
put forward the issue of power nonetheless, till the weak became the victim of merciless power. Every exploration by these writers exemplified the existence of ideas that united the issue of the reality of life with illussion and fantasy. This created a sort of impact that each writer posseses a strong mirror ability, a creativity that enable the content of the short story to get out from the usual features or in other words the short story writers could "think out of the box". The ability to create something new is a good omen that not only the Singapore literature began to shine but also the writers themselves worked hard to enliven the literary scene in Singapore.

Suratman Markasan and his colleagues who were in the short story selection panel for this anthology were with a view, "we believe that writers who dared to get out from the usual enclosure, not only raised a multitude of issues in their short stories, but they initiated a new dawn in the development of short story writing in Singapore." Jamal Ismail, for example with his two short stories that fathomed into his realm of absurdity had obviously become an example of the development of short story in Singapore in the new era. With his short stories, "Yang" and "Di Sebalik Fatamorgana" (On the Other Side of Mirage) by Jamal Ismail that mulled on the problems of life in modern times-what was it that man looked for in life? More apparently in the short story, "Di Sebalik Fatamorgana" by Jamal Ismail it subsribed to the concept of innovation. The story telling technique was attractive, wayward from conventional laws, but its essence about the love for one self was effective. This was portrayed by way of tidy connection between reality and imagination.

Short stories produced by writers in the 80 's, had slightly forayed from the usual stream. Many Singapore short story writers searched for new grounds as well as fresh writing techniques. While new writers emerged but at the same time Singapore lost its veteran writers. Among the new productive writers in the 80's are Peter Augustine Goh, Ahmad Awang, Iswardy, Anuar Othman and Abd. Wahab Hamzah. However, Ahmad Affandi Jamari, Jalil Montel and Jamal Ismail who had the stamina in producing good short stories still write occassionaly, while others fell into oblivion. The same goes for veteran writers like Mas, Masuri SN and Noor SI who were known to possess the art of story telling on their own had long stopped writing and quietly vanished from the current scene.

Short stories by Ahmad Affandi Jamari, "Hidup Seribu Tahun Lagi" (Live A Thousand More Years); "Pengembaraan" (A Journey) by Masuri SN and "Hati Lelaki" (The Heart of Men) by Noor SI were proofs that they 
could produce short stories that welcome the reader to think about the issue of those "who wanted to live forever", as portrayed by Ahmad Affandi Jamari. And Mas presented the daily problem of the youth, Masuri SN discusses about a new technique in short story writing and finally Noor SI with the issue of generation gap.

Evidently, the short stories produced by Singapore writers in the 80's from a standpoint there existed a multitude of themes and issues that emphasised the view point of the writers. This group did not put forward the same themes as the writers of Angkatan Sasterawan 50'an, but nonetheless they uplifted the issues of the difficulty of living in a city, moral collapse, leadership and other individual issues. According to the view of the Editing Committee of Temasik, "what attracted us these writers had their own strength and style of emphasising a view. Some used the form of comical insinuations and some were very serious in that. Some used satire while others improvised symbols in their creative works" (1987:xv). Based on this observation, it could be ascertained that the writing technique of the short story writers of the 80 's displayed maturity by correlating the past, the present and the future. This could be traced by the usage of flashback and foreshadowing, which expained the existence of unity between reality, illusion, imagination and fantasy. Obviously, such mixture was exemplified by the short story "Pindah" (Moving) by Iswardy and "Di Sebalik Fatamorgana" (On the Other Side of Mirage) by Jamal Ismail.

Through Temasik too, the audience could savour the works of Nor Hidayat, which abundantly brought the issues of religion, Peter Augustine with his short story "Musim Penyedaran II" (Season of Realization II) and S. Markasan with his short stories "Perempuan Kerudung Hitam" (A Girl With a Black Veil) and "Mereka Pencuri" (They ae Thieves), which also had the same issues in their short stories. In "Alam Barzakh" (The Realm of Transition), one get to witness the writer portraying the religiously learned who felt contented with the laws and tenets of Islam and faith but in reality he had to learn and practice more. And in "Musim Penyedaran II" (Season of Realization), Peter Augustine Goh, the writer of this short story, suggested that men who were sinful to immediately repent. Although these were not new issues, but the technique of presentation employed was interesting enough. By using the coach of a train as the location, Anjang experienced a strange event in which to all the passengers seemed old. In such a scenario, Anjang faced the characters of mak cik (aunt) and pak cik (uncle) who engaged in a dialogue about faith and belief. The issue discussed enabled the story 
telling to encompass the past, present and the future. Whereas, in Suratman Markasan's short stories, the elements of Islam were inserted, as in his short story, "Perempuan Kerudung Hitam" (The Girl with a Black Veil), which depicted the disposition to forgive the offenders. And in the short story "Mereka Pencuri" (They are Thieves), tales of responsible children who never fail to pray and who refuse to steal, all being derived from a sound religious training from their parents were inserted.

In the short story of the 80 's, we saw the Singapore short story writers in general presented the issue of the turbulent Singapore Malay society. Tackling the issue, they strongly criticized their society by providing ideas and meaningful proposals as to how to develop the lame Malay society, so that it could stand tall with the other races in Singapore. This issue could be seen in the short story, "Engkau Tidak Tahu" (You Don't Know) by Muhammad Ariff Ahmad, and the same issue is evident in the short story, "Ke Mana Hati Hendak Kubawa” (Where Would I Bring My Heart) by Mohamed Fuad Salim. The story telling technique in both these short stories still maintained a mimetic fiction with a slant toward "imitates actual life" (Stephen Minot, 1965:127).

As an academic, observer, author and a Singapore literary thinker, Suratman Markasan is with a view, "after looking at the creative works namely Malay short story and poetry today, there existed a strong bond between writers and poets with the turbulent nature of its society. They criticized their society" (1987:xv). However, the social criticism by writers and poets alike touched on trivial and peripheral matters, including individual ones. How is social criticism directed via the Temasik anthology? This had been portrayed in the short story, "Belaian" by Ahmad Awang. The issue of family as the essence of it all saw Ahmad Awang stingingly criticizing man's current problems. The children wished their parents would stay with them and take of their grand children. This sometimes give rise to family squabbles. This is a serious criticism that touches on the turbulent Singapore Malay society which left an open ended discourse to the reader. The story telling technique still remained with the conventional laws, while the issues presented were the usual ones, but what made them special is that they are universal.

Societal issues can be traced via the short stories, "Wasiat" (The Will), by A. Wahab Hamzah, "Kini" (Now) by Basiran Hj. Hamzah and "Pindah" (Moving) by Iswardy. Wahab in "Wasiat" depicted the problem of children on properties left by their parents. Basiran Hj. Hamzah in "Kini" showcased the issue of the elders who were ostracized by their children, so much so they ended in the old folk's homes. In "Pindah", Iswardy mulled about the issue 
of the elderly who did not practise religion but only realised it when it was too late. The story telling style of this short story is noteworthy. The opening managed to somewhat "tricked" the reader. The reader had in fact been in a dream but the maturity and the creativity of the writer draws the reader to be in the conscious state. Although it is characterized by invention, a short story that carries a message of epiphany would be impactful to the reader. Such style contains literary creativity and inspirational to the audience.

\section{CONCLUSION}

The compilation of 20 short stories written by Singapore Malay writers, will in a way be a reading and research resource for literary lovers outside Singapore to sample the beat and stream of the development of Malay literature in Singapore, especially short story. The study on twenty short stories is never exhaustive in representing the entire faces of the Singapore society. But what can be deduced, these twenty short stories would at least be the reflection of the Singapore way of life which is "one and the same" between Malaysia and Singapore. That is the definition of "Temasik", whereby the Singapore society is trying to look for its Singaporean identity. That is the reason as to why there is no short story with the title of "Temasik" in this anthology, because all that was told by the writers carry the meaning of "Temasik". The tendency of the Singapore writers in producing conventional and nonconventional short stories in the 80's nevertheless was a precursor toward the development of the short story genre in the 90's. This era saw the rise of non-Malay writers in Minfong Ho, Naa Govindasamy, Cheong Wei Yat, Gopal Baratham, Arthur Yap, M Balaktihnan and Wong Meng Voon. This mirrors two situations : (1) the existence of change and continuity in the short story genre; and (2) more impactful was the creation of an interesting identity in that Singapore literature belongs to all races. More importantly, this development had a serious implication on the development of e-literature. This genre emerged as a new discourse with the involvement of young writers known as Kelab Coretan Remaja (KCR) as the proponent of e-youth.

\section{REFERENCE}

Ali Ahmad, 1978. Asas Menganalisa Cereka. Kuala Lumpur: Dewan Bahasa dan Pustaka.

Amilah Ab.Rahman and Nor Azmah Shehidan (comp.), 2001. Orang di Jambatan: 
MALAY LITERATURE VOLUME 27 NUMBER 12014

Antologi Cerpen ASEAN. Kuala Lumpur: Dewan Bahasa dan Pustaka.

Hashim Awang, 1987. Glosari Istilah Kesusasteraan. Petaling Jaya: Fajar Bakti.

Lodge, David, 1992. The Art of Fiction. London: Penguin Books.

Minot, Stephen, 1966. Three Genres: The Writing of Poetry, Fiction and Drama. New Jersey: Prentice Hall.

Mohamed Pitchay Gani Mohamed Abdul Aziz. (ed.), 2005. Leksikon: Direktori Penulis Melayu Singapura Pasca 1965. Singapura: Angkatan Sasterawan ; Angkatan Sasterawan '50 \& National Library Board.

Suratman Markasan, 1987. Temasik: Antologi Cerpen Penulis-penulis Singapura. Kuala Lumpur: Dewan Bahasa \& Pustaka.

Suratman Markasan, 1991. Cerpen-cerpen Nusantara Mutakhir. Kuala Lumpur. Dewan Bahasa dan Pustaka.

(Translated by Malim Ghozali PK) 